\title{
SYNTHESIS, CHARACTERIZATION AND ANTIBACTERIAL STUDIES OF Co(II), Ni(II) AND Cu(II) COMPLEXES CONTAINING TRIPHENYLPHOSPHINE AND SCHIFF BASE LIGAND BASED ON SALICYLALDEHYDE
}

\author{
G. Gokulnath ${ }^{1}$, R. Manikandan ${ }^{2}$, P. Anitha ${ }^{3}$, and C. Umarani, ${ }^{1, 凶}$ \\ ${ }^{1}$ Department of Chemistry, Government Arts College (Autonomous), \\ Salem-636007, Tamilnadu, India \\ ${ }^{2}$ Department of Chemistry, Loyola College of Arts and Science, Mettala, Rasipuram, \\ Namakkal-636202, Tamil Nadu, India \\ ${ }^{3}$ Department of Chemistry, Government College of Engineering, \\ Salem-636011, Tamil Nadu, India \\ ${ }^{\otimes}$ Corresponding Author:jpchem20@gmail.com
}

\begin{abstract}
Schiff base ligand (HL) derived from the condensation of salicylaldehyde with 4-amino benzoic acid and its metal(II) complexes containing triphenylphosphine of the type $\left[\mathrm{MCl}\left(\mathrm{PPh}_{3}\right)(\mathrm{L})\right](\mathrm{M}=\mathrm{Ni}$, Co or $\mathrm{Cu}$; $\mathrm{L}=$ bidentate Schiff base ligand) were synthesized. The synthesized compounds were characterized by techniques of analytical and spectroscopic (FT-IR, electronic, ESI-Mass, 1H, 13C NMR, and 31P NMR). The antibacterial activities of the ligand and metal complexes were studied against Gram-positive bacteria and Gram-negative bacteria using the agar well diffusion method.

Keywords: Salicylaldehyde, Schiff Base, Metal Complexes, Spectroscopic Investigation, Antibacterial Activity

RASĀYAN J. Chem., Vol. 14, No.4, 2021

\section{INTRODUCTION}

Metal complexes of the Schiff bases have attracted great interest because of their extensive applications, including antimicrobial, ${ }^{1}$ anticancer, ${ }^{2}$ antitumor, ${ }^{3}$ antioxidant, ${ }^{4}$ anti-inflammatory, ${ }^{5}$ antiviral ${ }^{6}$ and herbicidal ${ }^{7}$ activities, in addition to catalytic ${ }^{8}$, thermal ${ }^{9}$ and electrochemical ${ }^{10}$ properties. Recently, Schiff bases metal complexes derived from salicylaldehyde derivatives have received generous attention. ${ }^{11-13}$ These compounds make use of phenolic $\mathrm{O}$ and imine $\mathrm{N}$ donor atoms which lead to typically stable bidentate coordinated complexes. ${ }^{14,15}$ Schiff base metal complexes containing neutral and anionic molecules as addition ligands are of recent attention in view of their solid-state structures and mainly, the complex structure consisting of triphenylphosphine derivatives are of particular magnitude due to their probable beneficial catalyst and biological activities. ${ }^{16-18}$ The present paper deals with the synthesis and characterization of Schiff base, 4-((2-hydroxybenzylidene)amino)benzoic acid ligand (HL) and their $\mathrm{Co}(\mathrm{II}), \mathrm{Ni}(\mathrm{II})$ and $\mathrm{Cu}(\mathrm{II})$ complexes containing triphenylphosphine ligand. These synthesized complexes were characterized by various physicochemical techniques. The antibacterial activities of the ligand and metal(II) complexes were examined.
\end{abstract}

\section{Materials and Physical Measurements}

\section{EXPERIMENTAL}

The solvents and chemicals used were chemically pure and AR grade. The solvents were purified and dried according to standard procedures. ${ }^{19}$ The precursors $\left[\mathrm{MCl}_{2}\left(\mathrm{PPh}_{3}\right)_{2}\right](\mathrm{M}=\mathrm{Co}, \mathrm{Ni}$ and $\mathrm{Cu})$ were prepared by the literature procedure. ${ }^{20}$ Elemental analyses of $\mathrm{C}, \mathrm{H}$ and $\mathrm{N}$ were measured using a Vario EL III elemental analyzer. FT-IR spectra of the compounds were recorded on a Nicolet Avatar model spectrometer from 4000 to $400 \mathrm{~cm}^{-1}$ using $\mathrm{KBr}$ pellets. Electronic spectra were carried out on Shimadzu UV-1650 PC spectrophotometer in 800-200 nm range using methanol as the solvent. ${ }^{1} \mathrm{H}$ NMR and ${ }^{13} \mathrm{C}$ NMR spectra were obtained in Jeol GSX - 400 instruments using TMS as the internal standard. ${ }^{31}$ P NMR 
spectrum was recorded in Joel GSX - 400 instruments using o-phosphoric acid as a reference. The electron spin resonance spectrum (ESR) of the powder sample was recorded with a JEOL JES-FA200 instrument in X-band frequencies at room temperature using 2,2'-diphenyl-1-picrylhydrazyl radical $\left(\mathrm{DPPH}^{*}\right)$ as an internal standard at SAIF-IIT, Madras. The ESI-Mass spectra were performed on LC-MS Q-ToF Micro Analyzer (Shimadzu) at SAIF-Panjab University, Chandigarh. Melting points were measured on a Technico micro heating table and are uncorrected.

\section{Synthesis of 4-((2-hydroxybenzylidene)amino)benzoic acid ligand (HL)}

A solution of 4-amino benzoic acid $(0.27 \mathrm{~g}, 2 \mathrm{mmol})$ in $10 \mathrm{~mL}$ of ethanol was added to a solution of 2hydroxy benzaldhyde $(0.25 \mathrm{~g}, 2 \mathrm{mmol})$ in $10 \mathrm{~mL}$ of warm ethanol and the resulting solution was refluxed for $4 \mathrm{~h}$. Yellow solid was obtained after cooling at room temperature. The product was filtered off, washed with cold ethanol and dried under vacuum.

\section{Synthesis of Metal(II) Complexes}

A warm ethanolic solution $(10 \mathrm{~mL})$ of 4-(2-hydroxybenzylideneamino) benzoic acid (HL) (0.5 mmol) was added to metal precursors $(0.5 \mathrm{mmol})$ in ethanol $(10 \mathrm{~mL})$. The resulting mixture was refluxed for 5 hours. A crystalline powder was obtained on slow evaporation. They were filtered off, washed with ethanol and dried under vacuum.

\section{Antibacterial Activity}

The antibacterial activity of the ligand and its metal(II) complexes was determined by using the agar well diffusion method. ${ }^{21}$ The compounds were studied for the inhibitory effect on the growth of different bacteria such as Staphylococcus aureus, Bacillus sphaericus, Pseudomonas aeruginosa and Escherichia coli. The concentration of the ligand and its metal(II) complexes is $0.6-1.5 \mu \mathrm{g} / \mathrm{mL}$ in DMSO for antibacterial studies. Each test bacterial was swabbed on sterile Muller-Hinton agar plates using a sterile cotton swab followed by punching wells of $6 \mathrm{~mm}$ diameter with the help of a sterile cork borer. The plates were incubated at $37^{\circ} \mathrm{C}$ overnight. After $24 \mathrm{~h}$, the antibacterial activities were expressed in terms of the diameter of the zone of inhibition (in $\mathrm{mm}$ ) of each bacterial species by different samples.

\section{RESULTS AND DISCUSSION}

The reaction of salicylaldehyde with 4-amino benzoic acid in ethanol yielded the ligand (HL). The synthesis of the metal(II) complexes was achieved by reacting one equivalent ethanolic solution of ligand (HL) with one equivalent metal precursor $\left[\mathrm{MCl}_{2}\left(\mathrm{PPh}_{3}\right)_{2}\right](\mathrm{M}=\mathrm{Co}, \mathrm{Ni}$ and $\mathrm{Cu})$ in ethanol (Scheme-1). The elemental analysis and physicochemical data of the ligand and their complexes are provided in Table-1.

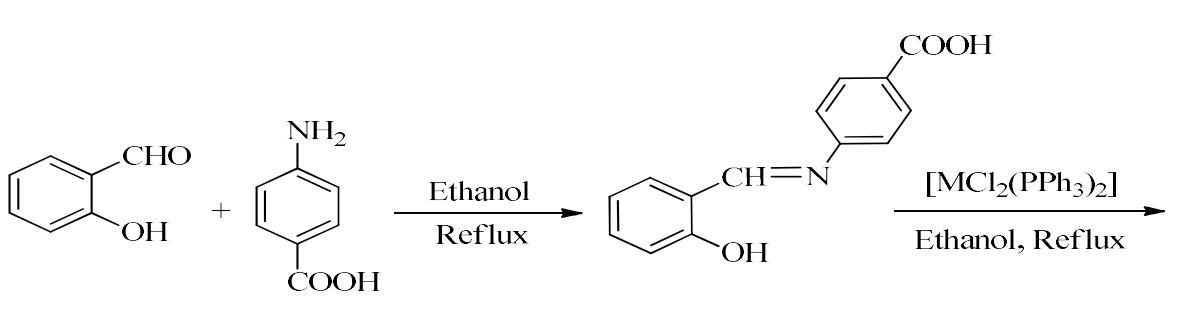

Scheme-1: Synthetic Route of Ligand and Complexes

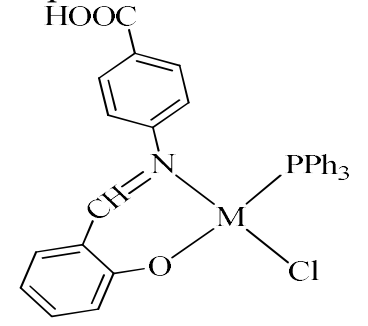

$(\mathrm{M}=\mathrm{Ni}, \mathrm{Co}$ or $\mathrm{Cu})$

\section{IR spectra}

The IR spectrum of the free ligand shows a strong vibration at $3506 \mathrm{~cm}^{-1}$ due to the hydroxyl group. This band vanished in the spectra of the new complexes suggesting that the ligand underwent deprotonation prior to coordination to metal ion. ${ }^{22}$. in addition, a band appeared in the region $1282 \mathrm{~cm}^{-1}$ due to the phenolic $\mathrm{C}-\mathrm{O}$ group of the free ligand being shifted to $1230-1264 \mathrm{~cm}^{-1}$ in the IR spectra of the complexes indicating the coordination through a phenolic oxygen atom. ${ }^{22}$ A medium sharp band at $1680 \mathrm{~cm}^{-1}$ due to the azomethine $\mathrm{C}=\mathrm{N}$ stretching frequency of the free ligand was shifted to a lower frequency in the spectra of the complexes $1651-1676 \mathrm{~cm}^{-1}$, indicating that the other coordination is through azomethine $\mathrm{N}$ 
RASĀYAN J. Chem.

Vol. 14 | No. 4 |2692-2697| October- December | 2021

atom. ${ }^{23}$ Both free ligand and the new complexes show the broad band around in the region of 3213-3315 $\mathrm{cm}^{-1}$ can be assigned to $\mathrm{COOH}$ group and this observation suggests that the non-participation of $\mathrm{COOH}$ group in bonding. On the other hand, the bands present in the 599-688 and 470-475 $\mathrm{cm}^{-1}$ ranges may be taken as an indication of the coordination between the metal ions with oxygen and nitrogen atoms, respectively. The bands due to triphenylphosphine were also present in the predictable region. ${ }^{23}$ The IR spectral data are given in Table-2.

Tables-1: Elemental Analysis and ESI Mass Spectral Data of Ligand and Metal(II) Complexes

\begin{tabular}{|c|c|c|c|c|c|c|}
\hline \multirow[t]{2}{*}{ Compound } & \multirow[t]{2}{*}{ Colour } & \multirow{2}{*}{$\begin{array}{l}\text { m.p. } \\
\left({ }^{\circ} \mathrm{C}\right)\end{array}$} & \multicolumn{3}{|c|}{$\begin{array}{l}\text { Elemental Analysis Data } \\
\text { Calculated (Found) (\%) }\end{array}$} & \multirow{2}{*}{$\begin{array}{l}\text { ESI Mass (m/z) } \\
\text { Calculated/Found }\end{array}$} \\
\hline & & & $\mathrm{C}$ & $\mathrm{H}$ & $\mathrm{N}$ & \\
\hline $\mathrm{HL}$ & Yellow & 156 & $69.70(69.35)$ & $4.19(4.66)$ & $5.81(5.61)$ & - \\
\hline$\left[\mathrm{CoCl}\left(\mathrm{PPh}_{3}\right)(\mathrm{L})\right]$ & Green & 210 & $64.39(64.23)$ & $4.22(4.67)$ & $2.35(2.62)$ & $596.91 / 597.10$ \\
\hline$\left[\mathrm{NiCl}\left(\mathrm{PPh}_{3}\right)(\mathrm{L})\right]$ & Brown & 197 & $64.42(63.72)$ & $4.22(3.92)$ & $2.25(2.56)$ & $596.67 / 596.07$ \\
\hline$[\mathrm{CuCl}(\mathrm{PPh} 3)(\mathrm{L})]$ & Yellow & 205 & $63.90(63.52)$ & $4.19(3.92)$ & $2.33(2.83)$ & $601.52 / 601.01$ \\
\hline
\end{tabular}

Table-2: IR Absorption Frequencies $\left(\mathrm{cm}^{-1}\right)$ and Electronic Spectral Data ( $\left.\mathrm{nm}\right)$ of Ligand and Metal(II) Complexes

\begin{tabular}{c|c|c|c|c|c|c}
\hline Compound & $v(\mathrm{COOH})$ & $v(\mathrm{OH})$ & $v(\mathrm{CN})$ & $v(\mathrm{M}-\mathrm{O})$ & $v(\mathrm{M}-\mathrm{N})$ & $\lambda_{\max }(\mathrm{nm})$ \\
\hline $\mathrm{HL}$ & 3213 & 3506 & 1680 & - & - & 250,310 \\
\hline$\left[\mathrm{CoCl}\left(\mathrm{PPh}_{3}\right)(\mathrm{L})\right]$ & 3315 & - & 1651 & 688 & 472 & $255,280,340,482$ \\
\hline$\left[\mathrm{NiCl}\left(\mathrm{PPh}_{3}\right)(\mathrm{L})\right]$ & 3278 & - & 1651 & 688 & 475 & $248,305,370,430$ \\
\hline$\left[\mathrm{CuCl}\left(\mathrm{PPh}_{3}\right)(\mathrm{L})\right]$ & 3313 & - & 1676 & 599 & 470 & $253,307,387,417$ \\
\hline
\end{tabular}

\section{Electronic Spectra}

The electronic spectrum of the free ligand exhibit bands at 250 and $310 \mathrm{~nm}$ corresponding to the $\mathrm{n} \rightarrow \pi^{*}$ transition of the azomethine and $\pi \rightarrow \pi^{*}$ transitions of the aromatic ring, respectively. The absorption bands observed for all the complexes in the regions of 248-307 and 340-387 nm are attributed to the intra ligand transitions within the coordinated ligand moiety and ligand-to metal charge transfer (LMCT) transitions. ${ }^{24}$ The band that appeared in this region $417-482 \mathrm{~nm}$ has been assigned to $\mathrm{d}-\mathrm{d}$ transition. ${ }^{25}$ The electronic spectral data are given in Table-2.

\section{NMR Spectra}

The ${ }^{1} \mathrm{H}$ NMR and ${ }^{13} \mathrm{C}$ NMR spectral data of ligand and Ni(II) complex are provided in Table-3. The singlet observed at $\boldsymbol{\delta} 12.95 \mathrm{ppm}$ in the ligand due to phenolic $\mathrm{OH}$ proton has disappeared in the ${ }^{1} \mathrm{H}$ NMR spectrum of $\mathrm{Ni}(\mathrm{II})$ complex. This revealed the coordination of ligand to $\mathrm{Ni}(\mathrm{II})$ through phenolic oxygen atoms. ${ }^{26}$ The ligand and their nickel complex show a sharp singlet at $\boldsymbol{\delta} 12.72$ and $12.55 \mathrm{ppm}$, respectively, which is due to $\mathrm{COOH}$ group. A singlet obtained at $\boldsymbol{\delta} 8.03$ in the spectra of the free ligand assigned to the azomethine proton undergoes a shift to $\boldsymbol{\delta} 8.85 \mathrm{ppm}$ in the metal complex, indicating the coordination of the azomethine nitrogen atom to the metal. The signals corresponding to the protons of the aromatic moieties of the ligand and their complex were obtained as multiplets in the range $\boldsymbol{\delta} 6.37-8.01 \mathrm{ppm}$. The ${ }^{13} \mathrm{C}$ NMR spectra of ligand and nickel complex showed a sharp peak at $\boldsymbol{\delta} 182.64$ and $191.62 \mathrm{ppm}$, which has been attributed to $\mathrm{COOH}$ carbon. The phenolic carbon $(\mathrm{C}-\mathrm{O})$ and azomethine $(\mathrm{CH}=\mathrm{N})$ carbon have exhibited peaks at $\boldsymbol{\delta} 165.29-167.26 \mathrm{ppm}$ and $\boldsymbol{\delta} 160.76-160.62 \mathrm{ppm}$ regions, respectively. In addition, all the aromatic carbon atoms exhibited their corresponding peaks in the region $\boldsymbol{\delta} 113.30-152.64 \mathrm{ppm}$ as expected. ${ }^{31} \mathrm{P}$ NMR spectrum of the nickel complex was recorded to confirm the presence of the triphenylphosphine group in the complex. A sharp singlet was observed at $\boldsymbol{\delta} 27.80 \mathrm{ppm}$ due to the presence of triphenylphosphine ligand in the complex.

\section{ESR Spectra}

The solid-state EPR spectra at X-band frequencies for copper(II) complex were recorded at room temperature (Fig.-1). The ESR spectrum of $\mathrm{Cu}$ (II) complex exhibited anisotropic signal with $\mathrm{g}_{\|}=2.20$ and $\mathrm{g}_{\perp}=2.10$ and $\mathrm{g}_{\text {aver. }}=1 / 3\left(\mathrm{~g}_{\perp}+2 \mathrm{~g}_{\|}\right)=2.13$. The trend in the observed " $\mathrm{g}$ " values $\mathrm{g}_{\|}>\mathrm{g}_{\perp}>\mathrm{g}_{\mathrm{e}}$ 
RASĀYAN J. Chem.

Vol. 14 | No. 4 |2692-2697| October- December | 2021

(2.0023) suggested that the unpaired electron lies predominantly in the $d^{2}-y^{2}$ orbital, which is in agreement with the electronic absorption spectroscopic assignments. In square planar complexes, the unpaired electron occupies the $\mathrm{dx}^{2}-\mathrm{y}^{2}$ orbital with ${ }^{2} \mathrm{~B}_{\mathrm{lg}}$ ground state resulting in $\mathrm{g}_{\|}>\mathrm{g}_{\perp}$.

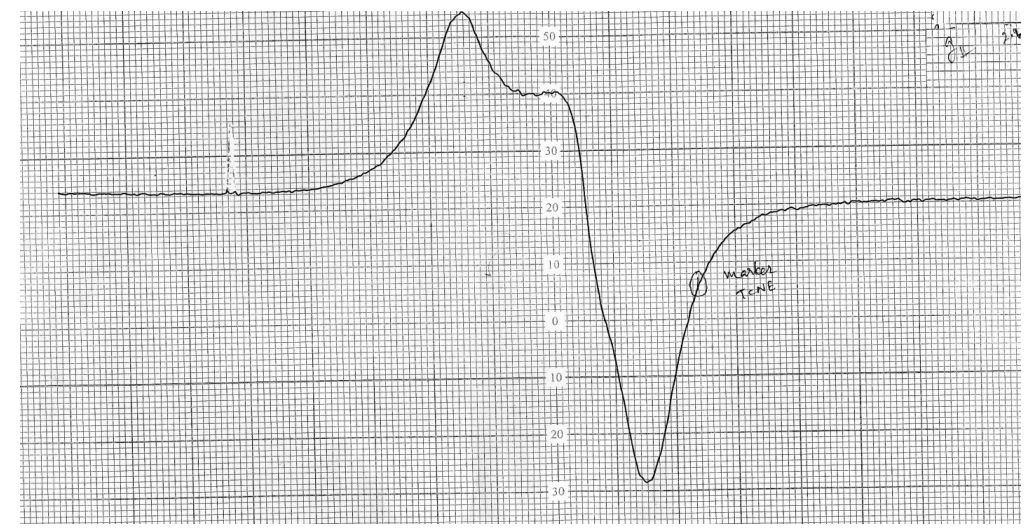

Fig.-1: ESR Spectrum of $\mathrm{Cu}(\mathrm{II})$ Complex

Table-3: ${ }^{1} \mathrm{H}$ NMR and ${ }^{13} \mathrm{C}$ NMR of Ligand and Ni(II) Complex

\begin{tabular}{|c|c|c|}
\hline Compound & ${ }^{1} \mathrm{H}$ NMR (ppm) & ${ }^{13} \mathrm{C}$ NMR \\
\hline HL & $\begin{array}{l}\mathrm{OH}), 12.72(\mathrm{COOH}), 8.03 \\
, 6.98-8.01(\text { Aromatic } \mathrm{H})\end{array}$ & $\begin{array}{l}182.64(\mathrm{COOH}), 165.29 \text { (phenolic C-O), } 160.76 \\
(\mathrm{CH}=\mathrm{N}), 117.16-152.64 \text { (Aromatic C). }\end{array}$ \\
\hline$[\mathrm{N}$ & $\begin{array}{l}12.55(\mathrm{COOH}), 8.85(\mathrm{CH}=\mathrm{N}), 6.37- \\
7.87(\text { Aromatic } \mathrm{H})\end{array}$ & $\begin{array}{l}\text { 191.62 (COOH), } 167.26 \text { (phenolic C-O), } 160.62 \\
(\mathrm{CH}=\mathrm{N}), 113.30-136.71 \text { (Aromatic C). }\end{array}$ \\
\hline
\end{tabular}

\section{Mass Spectra}

ESI-mass spectral analyses of the new complexes were recorded in order to confirm the molecular mass of the complexes (Fig.-2). The $\mathrm{m} / \mathrm{z}$ ( $\mathrm{m}$ stands for mass and $\mathrm{z}$ stands for the charge number of ions) values of the molecular ion peaks for the complexes $\left[\mathrm{CoCl}\left(\mathrm{PPh}_{3}\right) \mathrm{L}\right],\left[\mathrm{NiCl}\left(\mathrm{PPh}_{3}\right) \mathrm{L}\right]$ and $\left[\mathrm{CuCl}\left(\mathrm{PPh}_{3}\right) \mathrm{L}\right]$ were obtained at 597.10, 596.07, and $601.01[\mathrm{M}]^{+}$respectively. The calculated molecular masses corresponding to these complexes are 596.91, 596.67 and 601.52 . The obtained $\mathrm{m} / \mathrm{z}$ values of the complexes are in good agreement with the calculated molecular masses of complexes.

\section{Antibacterial Activity Study}

The antibacterial activities of ligand and metal(II) complexes were studied against the Gram positive bacteria (Staphylococcus aureus and Bacillus sphaericus) and Gram negative bacteria (Pseudomonas aeruginosa and Escherichia coli). The result of the antibacterial activities of ligand and metal complexes are given in Table-4. From the report, it is evident that the $\mathrm{Co}(\mathrm{II}), \mathrm{Ni}(\mathrm{II})$ and $\mathrm{Cu}$ (II) complexes are most active than the ligand. The higher activity of the complexes, as compared to the free ligand, can be understood in terms of the chelation theory. This theory explains that a decrease in the polarizability of the metal could develop the lipophilicity of the complexes. ${ }^{27}$

Table-4: Antibacterial Activities Data of Free Ligand and Metal(II) Complexes

\begin{tabular}{|c|c|c|c|c|c|c|c|c|c|c|c|c|c|c|c|c|}
\hline \multirow{3}{*}{ Compound } & \multicolumn{16}{|c|}{ Zone of Inhibition in ( $\mathrm{mm})$} \\
\hline & \multicolumn{4}{|c|}{ S. aureus } & \multicolumn{4}{|c|}{ P. aeruginosa } & \multicolumn{4}{|c|}{ E.coli } & \multicolumn{4}{|c|}{ B. sphaericus } \\
\hline & 0.6 & 0.9 & 1.2 & 1.5 & 0.6 & 0.9 & 1.2 & 1.5 & 0.6 & 0.9 & 1.2 & 1.5 & 0.6 & 0.9 & 1.2 & 1.5 \\
\hline $\mathrm{HL}$ & 8 & 8 & 8 & 8 & 8 & 10 & 12 & 14 & 10 & 13 & 15 & 17 & 10 & 12 & 14 & 16 \\
\hline$\left[\mathrm{CoCl}\left(\mathrm{PPh}_{3}\right) \mathrm{L}\right]$ & 13 & 15 & 17 & 19 & 18 & 20 & 22 & 24 & 13 & 15 & 17 & 17 & 11 & 13 & 15 & 17 \\
\hline$\left[\mathrm{NiCl}\left(\mathrm{PPh}_{3}\right) \mathrm{L}\right]$ & 10 & 13 & 16 & 19 & 14 & 18 & 20 & 24 & 12 & 14 & 16 & 18 & 13 & 16 & 18 & 20 \\
\hline$\left[\mathrm{CuCl}\left(\mathrm{PPh}_{3}\right) \mathrm{L}\right]$ & 16 & 18 & 20 & 22 & 13 & 15 & 17 & 17 & 12 & 14 & 16 & 18 & 16 & 18 & 20 & 22 \\
\hline
\end{tabular}


RASĀYAN J. Chem.

Vol. 14 | No. 4 |2692-2697| October- December | 2021
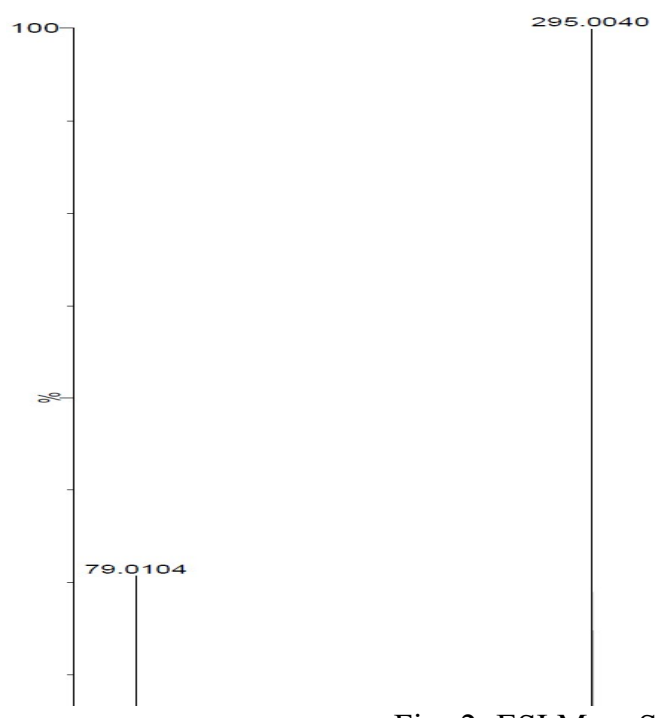

Fig.-2: ESI Mass Spectrum of $\mathrm{Cu}(\mathrm{II})$ Complex

CONCLUSION

Some metal(II) complexes containing triphenyl phosphine and Schiff base ligand were synthesized and characterized. The basis of analytical data and spectral studies revealed the square planar geometry proposed for $\mathrm{Ni}(\mathrm{II}), \mathrm{Co}(\mathrm{II})$ and $\mathrm{Cu}(\mathrm{II})$ complexes. The metal complexes exhibit more diverse antibacterial activity than ligand due to the reduction of the polarity of the metal ion.

\section{ACKNOWLEDGEMENT}

We express our sincere thanks to the SAIF-IIT Madras, STIC Cochin, VIT Vellore and SAIF Punjab University, Chandigarh for spectral studies.

\section{REFERENCES}

1. Y. Satyawana, R. Meena, R. V. Singh and N. Fahmi, Rasayan Journal of Chemistry, 12(4), 2328(2019), http://dx.doi.org/10.31788/RJC.2019.1245459

2. G. Puthilibai, and S. Vasudhevan, Rasayan Journal of Chemistry, 12(2), 855(2019), http://dx.doi.org/10.31788/RJC.2019.1225184

3. F. Zhao, W. Wang, W. Lu, L. Xu, S. Yang, X.M.Cai, M. Zhou, M. Lei, M. Ma, H.J. Xu and F. Cao, European Journal of Medicinal Chemistry, 146, 451(2018), https://doi.org/10.1016/j.ejmech.2018.01.041

4. B. Iftikhar, K. Javed, M.S.U. Khan, Z. Akhter, B. Mirza and V. Mckee, Journal of Molecular Structure, 1155, 337(2018), https://doi.org/10.1016/j.molstruc.2017.11.022

5. M.S. Alam, J.H. Choi and D.U. Lee, Bioorganic and Medicinal Chemistry, 20, 4103(2012), https://doi.org/10.1016/j.bmc.2012.04.058

6. K.S. Kumar, S. Ganguly, R. Veerasamy and E. De Clercq, European Journal of Medicinal Chemistry, 45, 5474(2010), https://doi.org/10.1016/j.ejmech.2010.07.058

7. S.B. Desai, P.B. Desai and K.R. Desai, Heterocyclic Communications, 7, 83(2001), https://doi.org/10.1515/HC.2001.7.1.83

8. S. Sarkar, S.K. Nag, A.P. Chattopadhyay, K. Dey, Sk M. Islam, A. Sarkar and S. Sarkar, Journal of Molecular Structure, 1160, 9(2018), https://doi.org/10.1016/j.molstruc.2018.01.035

9. M.A. Ayoub, E.H. Abd-Elnasser, M.A. Ahmed and M.G. Rizk, Journal of Molecular Structure, 1163, 379(2018), https://doi.org/10.1016/j.molstruc.2018.03.006

10. R.N. Egekenze, Y. Gultneh and R. Butcher, Inorganica Chimica Acta, 478, 232(2018), https://doi.org/10.1016/j.ica.2018.01.027

11. E. Canpolat and M. Kaya, Journal of Coordination Chemistry, 57, 1217(2004), https://doi.org/10.1080/00958970412331285913 
RASĀYAN J. Chem.

Vol. 14 | No. 4 |2692-2697| October- December | 2021

12. J. Panda, L. Adhikari, A.Pal, S.S. Rout, S. Pattanaik and P. Pradhan, Rasayan Journal of Chemistry, 13(1), 556(2020), http://dx.doi.org/10.31788/RJC.2020.1315477

13. H. Keypour, M. Shayesteh, M. Rezaeivala, F. Chalabian, Y. Elerman and O. Buyukgungor, Journal of Molecular Structure, 1032, 62(2013) https://doi.org/10.1016/j.molstruc.2012.07.056

14. H. Temel, S. Ilhan, A. Kiliçl and E. Tas, Journal of the Chinese Chemical Society, 53, 1027(2006), https://doi.org/10.1002/jccs.200600136

15. G. Bagihalli, S. Patil, P. Badami, Journal of the Iranian Chemical Society, 6, 259(2009), https://doi.org/10.1007/BF03245833

16. M. Muthu Tamizh, K. Mereiter, K. Kirchner and R. Karvembu, Journal of Organometallic Chemistry, 700, 194(2012), https://doi.org/10.1016/j.jorganchem.2011.12.016

17. R. Prabhakaran, S.V. Renukadevi, R. Karvembu, R. Huang, J. Mautz, G. Huttner, R. Subashkumar and K. Natarajan, European Journal of Medicinal Chemistry, 43, 268(2008), https://doi.org/10.1016/j.ejmech.2007.03.006

18. G. Erre, S. Enthaler, K. Junge, S. Gladiali and M. Beller, Coordination Chemistry Reviews, 252, 471(2008), https://doi.org/10.1016/j.ccr.2007.09.021

19. A.I. Vogal, Textbook of Practical Organic Chemistry, ELBS London, $5^{\text {th }}$ Ed, (1989).

20. L.M. Venanzi, Journal of the Chemical Society, 719(1958) https://doi.org/10.1039/JR9580000719

21. M. Balouiri, M. Sadiki and S.K. Ibnsouda, Journal of Pharmaceutical Analysis, 6, 71(2016), https://doi.org/10.1016/j.jpha.2015.11.005

22. M. MuthuTamizh, B. Varghese, A. Endo and R. Karvembu, Spectrochimica Acta Part A, 77, 411(2010), https://doi.org/10.1016/j.saa.2010.06.004

23. M. MuthuTamizh, K. Mereiter, K. Kirchner, B.R. Bhat and R. Karvembu, Polyhedron, 28, 2157(2009), https://doi.org/10.1016/i.poly.2009.04.021

24. M.B. Ferrari, S. Capacchi, F. Bisceglie, G. Pelosi and P. Tarasconi, Inorganica Chimica Acta, 312, 81(2001), https://doi.org/10.1016/S0020-1693(00)00339-X

25. N.C. Kasuga, K. Sekino, C. Koumo, N. Shimala, M. Ishikawa and K. Nomiya, Journal of Inorganic Biochemistry, 84, 55(2001), https://doi.org/10.1016/S0162-0134(00)00221-X

26. S. Guveli, N. Ozdemir, T.B. Demirci, B. Ulkuseven, M. Dincer and O. Andac, Polyhedron, 29, 2393(2010), https://doi.org/10.1016/j.poly.2010.05.004

27. B.G. Tweedy, Phytophatology, 55, 910(1964).

[RJC-6480/2021] 